\title{
The Ecological Relationship of Groundwater-Soil-Vegetation in the Oasis-Desert Transition Zone of the Shiyang River Basin
}

\author{
Le Cao ${ }^{1,2,3, * \mathbb{C}}$, Zhenlong Nie ${ }^{1}$, Min Liu ${ }^{1} \mathbb{C}$, Lifang Wang ${ }^{1}$, Jinzhe Wang ${ }^{1}$ and Qian Wang ${ }^{1}$ \\ 1 Institute of Hydrogeology and Environmental Geology, Chinese Academy of Geological Sciences, \\ Shijiazhuang 050061, China; nzlngj@163.com (Z.N.); agnes0505@163.com (M.L.); wlffighting@163.com (L.W.); \\ wjz5885970@163.com (J.W.); wangqian870731@gmail.com (Q.W.) \\ 2 Chinese Academy of Geological Sciences, China University of Geosciences (Beijing), Beijing 100083, China \\ 3 Key Laboratory of Groundwater Sciences and Engineering, Ministry of Natural Resources, \\ Shijiazhuang 050061, China \\ * Correspondence: lecao973@cugb.edu.cn
}

check for updates

Citation: Cao, L.; Nie, Z.; Liu, M.; Wang, L.; Wang, J.; Wang, Q. The Ecological Relationship of

Groundwater-Soil-Vegetation in the Oasis-Desert Transition Zone of the Shiyang River Basin. Water 2021, 13, 1642. https://doi.org/10.3390/ w13121642

Academic Editor: Frédéric Frappart

Received: 13 May 2021

Accepted: 8 June 2021

Published: 11 June 2021

Corrected: 31 March 2022

Publisher's Note: MDPI stays neutral with regard to jurisdictional claims in published maps and institutional affiliations.

Copyright: (c) 2021 by the authors. Licensee MDPI, Basel, Switzerland. This article is an open access article distributed under the terms and conditions of the Creative Commons Attribution (CC BY) license (https:/ / creativecommons.org/licenses/by/ $4.0 /)$.
Abstract: Groundwater is an important ecological water source in arid areas. Groundwater depth (GWD) is an important indicator that affects vegetation growth and soil salinization. Clarifying the coupling relationship between vegetation, groundwater, and soil in arid areas is beneficial to the prevention of environmental problems such as desertification and salinization. Existing studies lack research on the water-soil-vegetation relationship in typical areas, especially in shallow groundwater areas. In this study, the shallow groundwater area in Minqin, northwest China, was taken as study area, and vegetation surveys and soil samples collection were conducted. The relationships between vegetation fractional coverage (VFC) and GWD, soil salinity, soil moisture, and precipitation were comprehensively analyzed. The results showed low soil salinity in the riparian zone and high soil salinity in other shallow-buried areas with salinization problems. Soil salinity was negatively correlated with VFC $(R=-0.4)$. When soil salinity $>3 \mathrm{~g} / \mathrm{kg}$, VFC was less than $20 \%$. Meanwhile, when GWD $>10 \mathrm{~m}, \mathrm{VFC}$ was usually less than $15 \%$. In the areas with soil salinity $<3 \mathrm{~g} / \mathrm{kg}$, when GWD was in the range of 4-10 m, VFC was positively correlated with soil moisture content $(\mathrm{R}=0.99)$, and vegetation growth mainly depended on surface soil water, which was significantly affected by precipitation. When GWD was less than $4 \mathrm{~m}$, VFC was negatively correlated with GWD $(\mathrm{R}=-0.78)$, and vegetation growth mainly relied on groundwater and soil water. There are obvious ecological differences in the shallow-buried areas in Minqin. Hence, it is reasonable to consider zoning and grading policies for ecological protection.

Keywords: groundwater depth (GWD); soil salinity; soil moisture; vegetation fractional coverage (VFC); NDVI; ecological relationship; Shiyang River Basin

\section{Introduction}

Desertification is the main ecological and environmental problem in arid areas [1-3], and vegetation is the main body of ecology in arid areas. Maintaining high vegetation coverage is the key to preventing desertification [4,5]. As vegetation growth relies on water, groundwater is an important ecological water source in addition to limited precipitation [6-8]. Groundwater depth (GWD) is an important factor affecting the growth of ecological vegetation [9-12]. Greater GWD leads to lower vegetation fractional coverage (VFC) [9,11], whereas lesser GWD causes salinization [13], which can restrict vegetation growth and affect VFC. Therefore, studying the ecological relationship between GWD, soil, and vegetation has important scientific significance.

The Shiyang River Basin in China faces serious salinization [14] and desertification problems [15], both of which are closely related to the GWD, especially in the Minqin Oasis at the lower reaches of the basin. After nearly 60 years of excessive groundwater exploitation, the GWD in the basin has increased significantly, affecting the growth of 
natural vegetation around the oasis. The sandstorm intrusion from the Badain Jaran Desert to the northwest of the oasis has gradually expanded $[16,17]$, and the Badain Jaran Desert is now close to become merging with the Tengger Desert in the east to the oasis. Sandstorms in this area are also one of the main sources of sandstorms in China [18]. In addition to the increase of the desertification area, the proportion of salinized soil accounts for $80 \%$ of the Minqin area [14], and the salinization problem in this area is extremely serious. Therefore, studying the ecological value of groundwater in the basin to natural vegetation, the GWD, and the ecological relationship between soil and vegetation is of important significance to the ecological protection, management, and restoration of this area.

Many scholars have conducted research on the ecological environmental problems (desertification and salinization) related to groundwater and vegetation in the Minqin area [14-16,19-21]. Huang [19,22,23] and Chunyu [24] studied the dynamic simulation of the oasis driven by ecological water transfer and its significance for the restoration of natural oases in arid inland basins, and obtained an optimal water diversion amount of 45 million $\mathrm{m}^{3}$. Cao [25] concluded that the most suitable groundwater depth for natural vegetation growth in the Minqin Oasis was 2.5-3.9 m, which is not completely consistent with other basins in Northwest China [26-28]. Wang [29,30] improved the theory and method of groundwater function evaluation and regionalization, and delineated the nature reserves of groundwater maintaining vegetation ecology, which are mainly distributed in the shallow groundwater buried areas. Ding [16] and Ren [17] investigated the source and spatiotemporal pattern of sand migration in the Minqin Oasis. Yang [14] reported that the area of soil salinization in the Minqin Oasis has gradually increased in recent years. The degree of salinization is high in spring and low in autumn, and a large proportion of the salinized land is related to climate and hydrological factors. Liu [31] investigated the spatial distribution characteristics of soil water and salt under different land use types in Minqin Oasis. The average salt content is $47.02 \mathrm{~g} / \mathrm{kg}$ and the degree of salinization is severe. Existing studies have mostly focused on the analysis of regional and basinscale remote sensing of vegetation coverage as well as salinization degree and evolution. However, the analysis of the coupling effect of groundwater, salinization, and ecological vegetation is still lacking. Detailed analysis of the groundwater ecological effects based on the spatial heterogeneity of the Minqin area also required, especially for the study of shallow groundwater areas.

In this study, we conducted a vegetation ecological survey, measured GWD, and collected groundwater and soil samples in the shallow GWD area of the Shiyang River Basin. By analyzing the ecological relationship of groundwater-soil-vegetation, the main factors that control and affect the VFC in the region were examined. By combining the characteristic differences of basic ecological conditions with zoning, targeted ecological protection and management suggestions were proposed. The objective of this study is to clarify the VFC under the control of GWD and soil salt in the oasis-desert transition zone of the Shiyang River Basin and obtain important ecological GWD and salinization indicators, and provide a reference and scientific basis for the formulation of ecological policies in the basin.

\section{Materials and Methods}

\subsection{Study Area}

The Shiyang River Basin is located in the eastern part of Gansu Province, China. It is one of the three inland river basins in the Hexi Corridor, with a total area of $4.16 \times 10^{4} \mathrm{~km}^{2}$ [32]. The Minqin Basin is located in the lower reaches of the Shiyang River Basin with an area of about $1.58 \times 10^{4} \mathrm{~km}^{2}$. The northwestern part is the Badain Jaran Desert, the southeastern part is the Tengger Desert (Figure 1), and the central part of the basin is the Minqin Oasis. The study area is mainly located in the oasis and desert transition zone from $38^{\circ} 00^{\prime} \mathrm{N}$ to $39^{\circ} 20^{\prime} \mathrm{N}$ and $102^{\circ} 37^{\prime} \mathrm{E}$ to $103^{\circ} 55^{\prime} \mathrm{E}$. These areas are subject to serious ecological problems and risks. The Minqin Oasis area is characterized by a typical arid desertification climate with an average annual temperature of $7.8^{\circ} \mathrm{C}$, an average annual 
precipitation of about $116.5 \mathrm{~mm}$, and an average annual evaporation of $2308 \mathrm{~mm}$ [33]. The landform types include mobile dunes, semi-fixed dunes, fixed dunes, interlaced deserts, and Gobi. Shrubs are the dominant component of natural vegetation in the area, and include Nitraria spp., Tamarix spp., Haloxylon ammodendron, Kalidium foliatum, Reaumuria soongorica, and Artemisia arenaria. The trees include Populus euphratica, Populus gansuensis, Elaeagnus angustifolia, and Salix matsudana. The herbs are mainly Phragmites australis, Achnatherum splendens, Sophora alopecuroides L., Bassia dasyphylla, and Agriophyllum squarrosum [34-36].

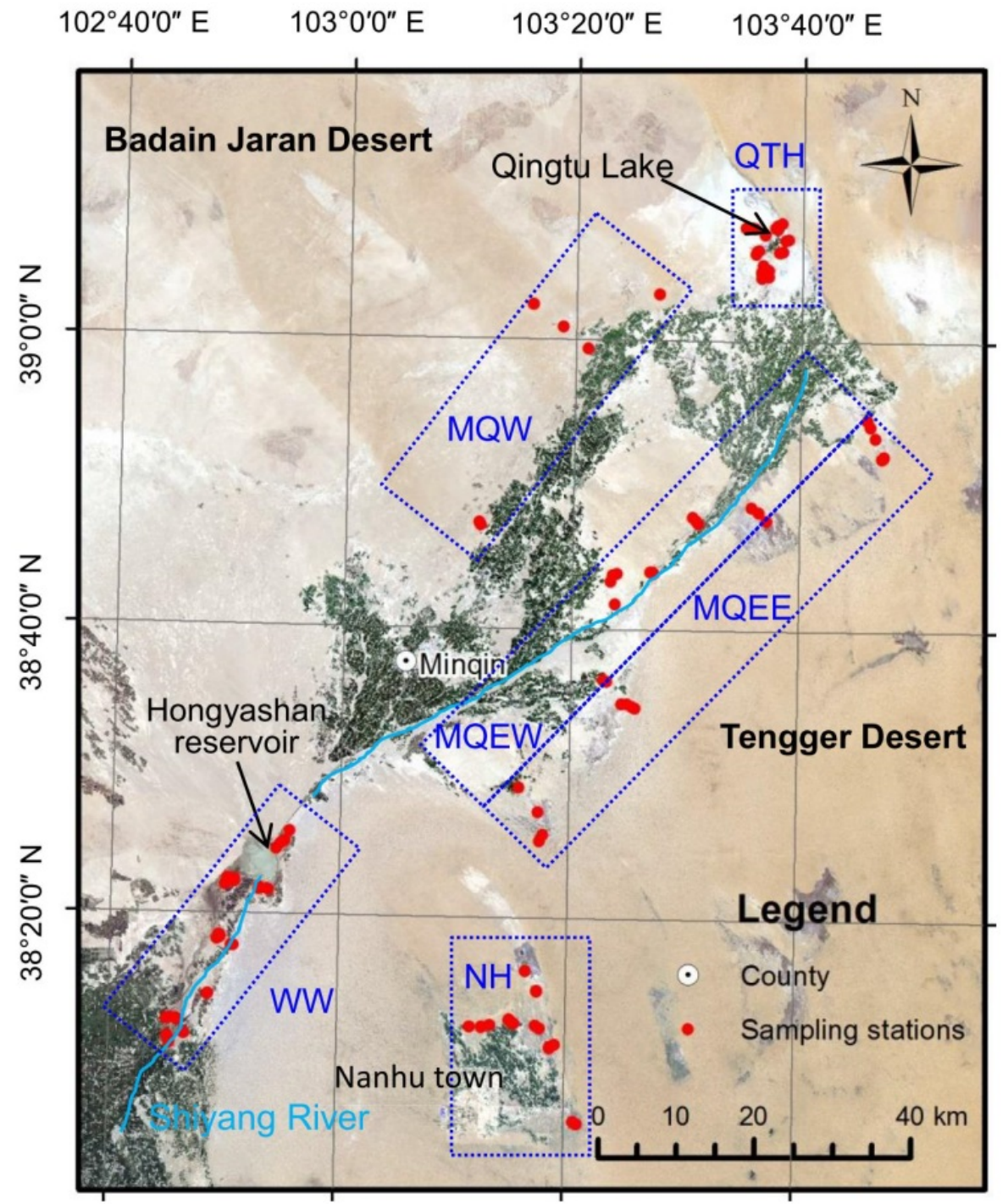

Figure 1. Remote-sensing image and sampling plots of the lower reaches of Shiyang River Basin.

In recent years, the GWD of agricultural irrigation area in the Minqin area has been around $15-35 \mathrm{~m}[25,37,38]$. The shallow groundwater area $(\mathrm{GWD}<15 \mathrm{~m})$ is mainly distributed in the oasis-desert transition zone around the irrigation area [25], the riparian zone [35], and the Qingtu Lake Wetland in the terminal lake of the Shiyang River [19]. According to the geographical location, landform, groundwater depth, and vegetation community, the shallow groundwater area was divided into six zones; detailed information is shown in Figure 1 and Table 1. These zones represent the riparian zone in the middle reaches (WW), the shallow groundwater area in Nanhu Town $(\mathrm{NH})$, Qingtu Lake wetland $(\mathrm{QTH})$, the west of Minqin oasis (MQW), Minqin Oasis (MQEW) and the east of Minqin oasis (MQEE). 
Table 1. Sampling sites information and the vegetation communities.

\begin{tabular}{|c|c|c|c|c|c|}
\hline $\begin{array}{c}\text { Site } \\
\text { Abbreviation }\end{array}$ & Landform & $\begin{array}{l}\text { Number of } \\
\text { Quadrats }\end{array}$ & $\begin{array}{l}\text { Groundwater } \\
\text { Depth }(\mathrm{m})\end{array}$ & Vegetation Types & Typical Communities \\
\hline $\mathrm{NH}$ & $\begin{array}{l}\text { Oasis-Desert } \\
\text { Transition } \\
\text { Zone/Wetland }\end{array}$ & 17 & $1.4-5.9$ & Shrubs/Herbs & Haloxylon ammodendron/Kalidium foliatum \\
\hline WW & Riparian zone & 26 & $1.3-6.0$ & Trees/Shrubs/Herbs & $\begin{array}{l}\text { Elaeagnus angustifolia/Tamarix } \\
\text { spp./Achnatherum splendens }\end{array}$ \\
\hline QTH & Desert/Wetland & 24 & $1.1-4.0$ & Shrubs/Herbs & Kalidium foliatum/Phragmites australis \\
\hline MQW & $\begin{array}{l}\text { Oasis-Desert } \\
\text { Transition Zone }\end{array}$ & 8 & $9.0-17.8$ & Shrubs/Herbs & Haloxylon ammodendron/Tamarix spp. \\
\hline MQEW & $\begin{array}{l}\text { Oasis-Desert } \\
\text { Transition Zone }\end{array}$ & 15 & $5.2-20.8$ & Shrubs/Herbs & Haloxylon ammodendron/Nitraria spp. \\
\hline MQEE & $\begin{array}{l}\text { Oasis-Desert } \\
\text { Transition Zone }\end{array}$ & 14 & $1.97-5.0$ & Trees/Shrubs/Herbs & Kalidium foliatum/Achnatherum splendens \\
\hline
\end{tabular}

\subsection{Data Sources and Methods}

The ecological survey was conducted in August 2018. According to different landform types and GWD intervals [25,37], representative plots in each district were selected to perform tree surveys with $30 \times 30 \mathrm{~m}^{2}$ vegetation quadrats. Within the large quadrat, five $5 \times 5 \mathrm{~m}^{2}$ quadrats were arranged in the four corners and the center according to the diagonal method to investigate shrubs. Within each shrub quadrat, a $1 \times 1 \mathrm{~m}^{2}$ quadrat was set up to conduct herb surveys. The ecological survey recorded the community types (trees, shrubs, and herbs), number of vegetation species, number of single species, coverage, growth, and other ecological indicators [39]. The importance of vegetation in the quadrat was ranked according to the coverage of each species.

In the center of the quadrat, soil samples were collected at $20 \mathrm{~cm}$ intervals for a maximum depth of $1 \mathrm{~m}$ [31]. Five samples were thus taken from each sampling point, stored in aluminum boxes and Ziplock bags, and tested for the soil moisture content and soluble salt. The moisture content was determined using the drying method [40]. The averaged value of the five samples was calculated and used as the soil characteristic data of the sampling point. The GWD was measured using a Luoyang shovel and steel tape.

The normalized difference vegetation index (NDVI) is a commonly used indicator for evaluating vegetation development. Landsat NDVI data have been widely used for studying changes in regional ecological environments [8,19,20,41-43]. In general, NDVI values range between -1 and 1 . A high NDVI value indicates that the vegetation is welldeveloped, whereas a low NDVI value indicates that the vegetation is in poor condition. This study used the Landsat satellite data (from 1980 to 2018) with a temporal resolution of $16 \mathrm{~d}$ and a spatial resolution of $30 \mathrm{~m}$. Firstly, the satellite image was preprocessed using atmospheric and geometric correction. Then, image stitching, cropping, and band calculation were performed. Finally, the maximum value extraction and annual average calculation were performed.

The vegetation fractional coverage is estimated using NDVI and the following formula [44]:

$$
\mathrm{VFC}=\frac{\mathrm{NDVI}-\mathrm{NDVI}_{\min }}{\mathrm{NDVI}_{\max }-\mathrm{NDVI}_{\min }} \times 100 \%,
$$

where VFC is the vegetation fractional coverage and $\mathrm{NDVI}_{\min }$ and $\mathrm{NDVI}_{\max }$ are NDVI values with cumulative probabilities of $5 \%$ and $95 \%$, respectively.

The long-term dynamic observation data of groundwater were obtained from the Shiyang River Administration. They include the data of typical groundwater depth monitoring wells in the Minqin area (1980-2016) and were used to calculate the annual average GWD. 
The meteorological data of the Minqin area were downloaded from the China Meteorological Science Data Sharing Service Network (http:/ / data.cma.cn; accessed on 1 July 2019) of the China Meteorological Administration. These data mainly include air temperature (T), relative humidity (RH), and precipitation (P) from 2004 to 2016. The annual average temperature, annual average relative humidity, and annual rainfall were calculated here based on the above data.

\section{Results}

\subsection{Surface Soil Moisture and Salt Content}

The average surface soil moisture contents (Figure 2a) of the areas in descending order were QTH > MQEE > NH > MQEW > WW > MQW. The soil moisture contents of all areas ranged from $0 \%$ to $30 \%$. MQW had the lowest average soil moisture content (only $2.5 \%$ ), whereas QTH had the highest average soil moisture content (about 16\%). However, the soil moisture content of QTH varied widely (5-30\%).

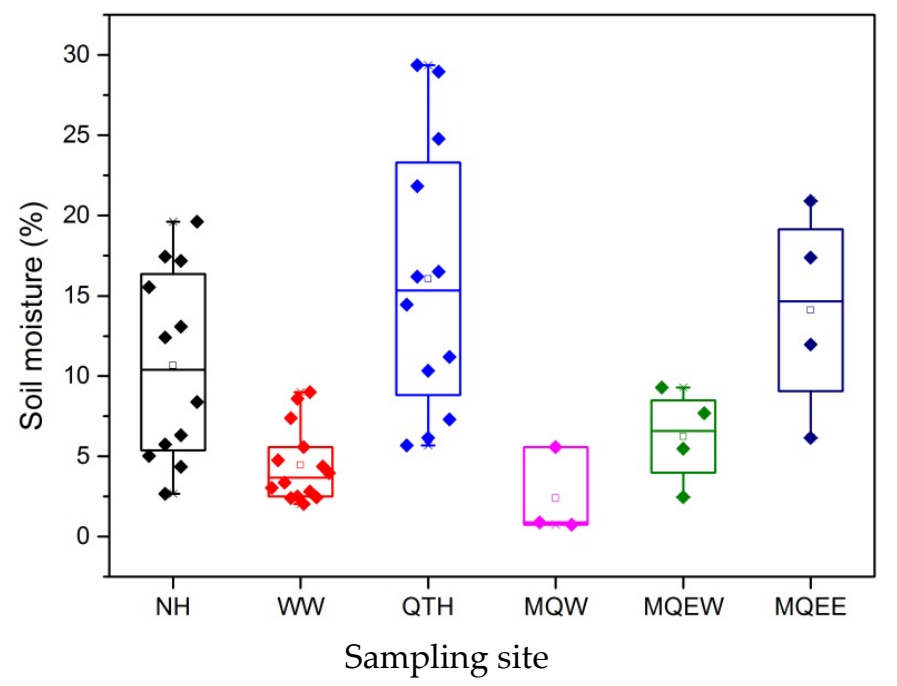

(a)

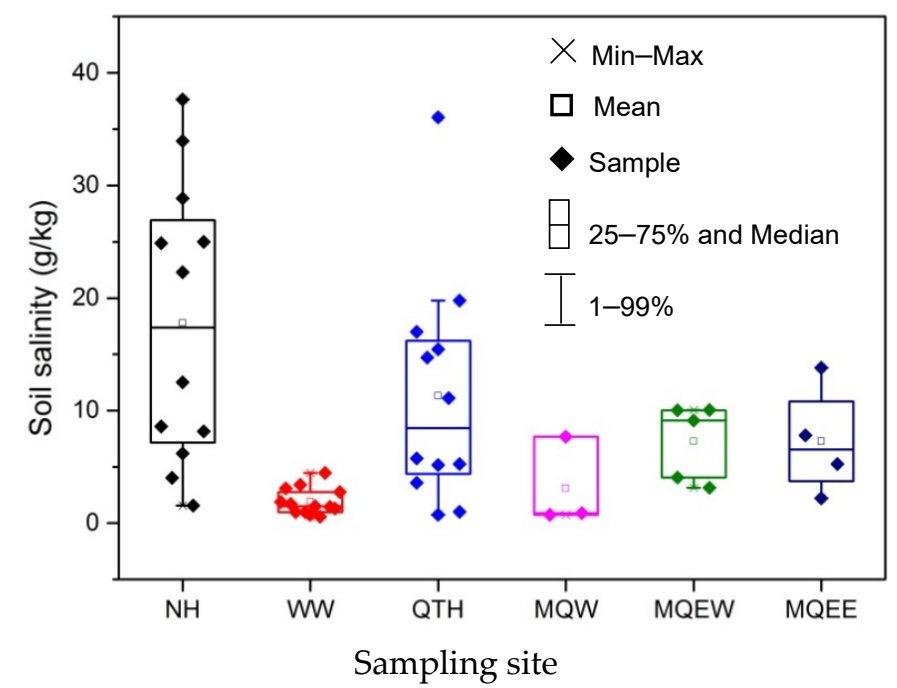

(b)

Figure 2. Surface soil moisture and salinity in different sampling sites: (a) surface soil moisture; (b) surface soil salinity.

The average surface soil salt contents (Figure $2 b$ ) of the areas in descending order were $\mathrm{NH}>\mathrm{QTH}>\mathrm{MQEE}>\mathrm{MQEW}>\mathrm{MQW}>\mathrm{WW}$. The salt contents of all areas ranged from 0 to $40 \mathrm{~g} / \mathrm{kg}$. The average salt content of WW was the lowest (at $1.5 \mathrm{~g} / \mathrm{kg}$ ), whereas that of $\mathrm{NH}$ was the highest (approximately $17.5 \mathrm{~g} / \mathrm{kg}$ ). The soil salt content of $\mathrm{NH}$ varied from 2 to $38 \mathrm{~g} / \mathrm{kg}$. With the exception of the WW area, the average salt content of the other five areas exceeded $3 \mathrm{~g} / \mathrm{kg}$, indicating salinized land.

\subsection{Ecological Vegetation Coverage and Groundwater Depth}

The remote sensing data showed the average VFC of each area (Figure 3 or Figure 4a). The VFCs of the areas in descending order were as follows: WW $>$ MQEE $>$ QTH $>$ MQEW $>\mathrm{NH}>\mathrm{MQW}$. The VFCs of all areas were less than $60 \%$. The average VFC of WW was the highest at $32 \%$, which indicated medium vegetation coverage. The VFC of MQW was the lowest at $8 \%$, which indicated mostly bare land. In contrast, the VFCs of other areas ranged from 10 to $20 \%$ and were classified as medium and low vegetation coverage areas. The VFCs of the quadrats in the WW area varied widely (with a maximum of $60 \%$ and a minimum of $2 \%$, with a high coefficient of variation. 


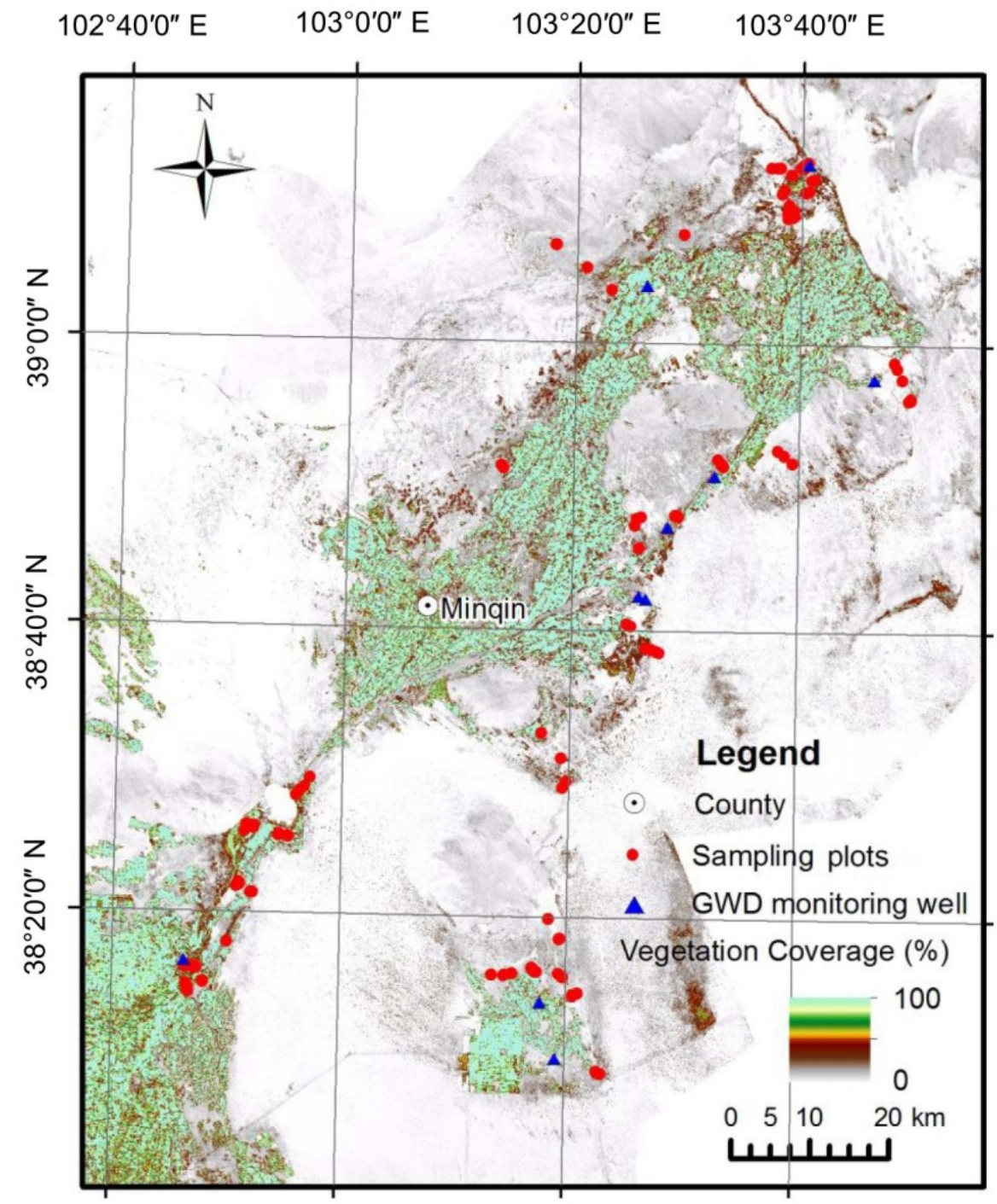

Figure 3. Distribution of groundwater depth (GWD) and vegetation fractional coverage (VFC).

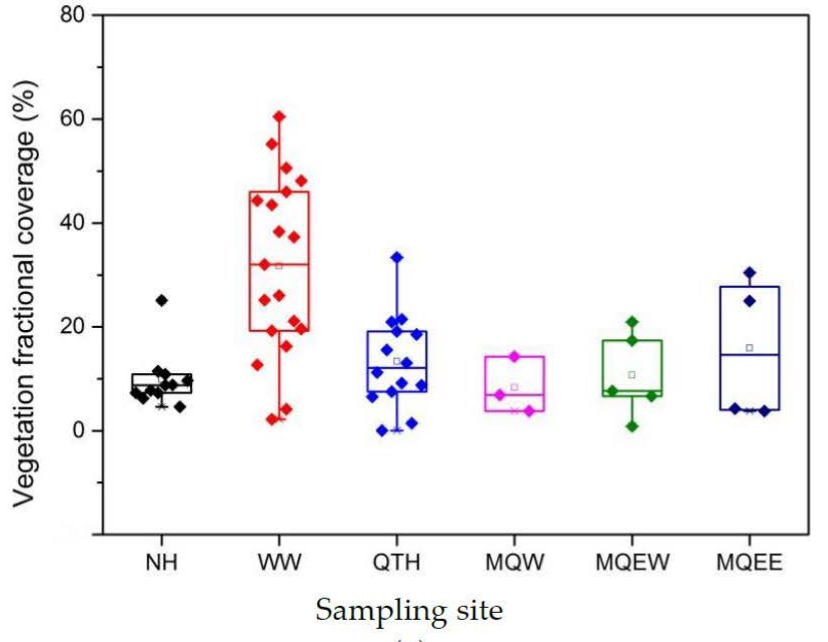

(a)

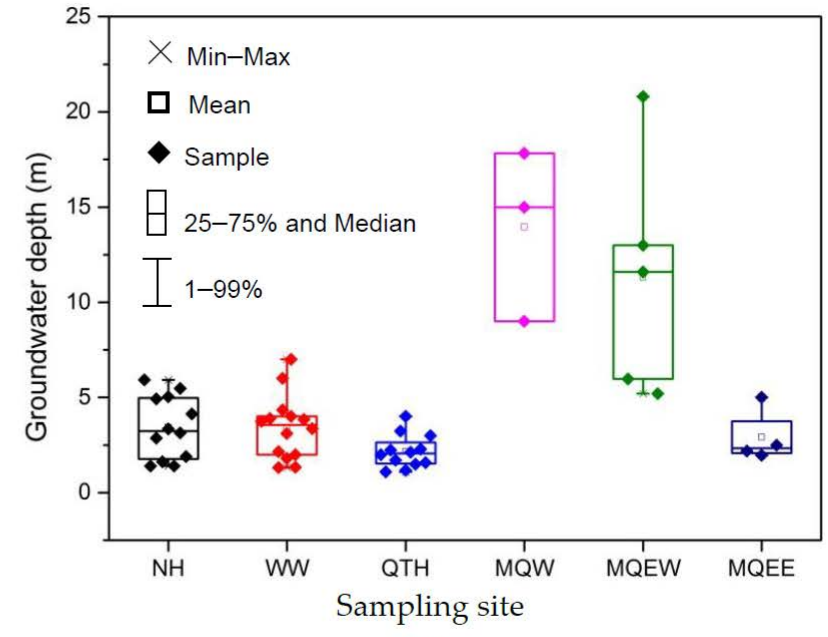

(b)

Figure 4. Vegetation fractional coverage and groundwater depth in different sampling sites: (a) vegetation fractional coverage; (b) groundwater depth. 
The GWDs of the areas in descending order were MQW > MQEW > NH > MQEE $>$ QQ > QTH (Figure 4b). The average GWD in MQW was $13.94 \mathrm{~m}$; that in MQEW was $11.31 \mathrm{~m}$; those in WW and NH were similar ( $3.42 \mathrm{~m}$ and $3.43 \mathrm{~m}$, respectively); those in QTH and MQEE were less than $3 \mathrm{~m}$; and that in QTH, at $2.16 \mathrm{~m}$, was the lowest.

The vegetation quadrats demonstrate that a combination of shrubs and herbs is the main community type in the study area (Figure 5). There were 66 quadrats of this type, accounting for $71 \%$ of all investigated quadrats. The average VFC was $15 \%$. The number of communities with trees was small, and they were only distributed in the WW area. In the communities with trees, the VFC was significantly higher (25-45\%).

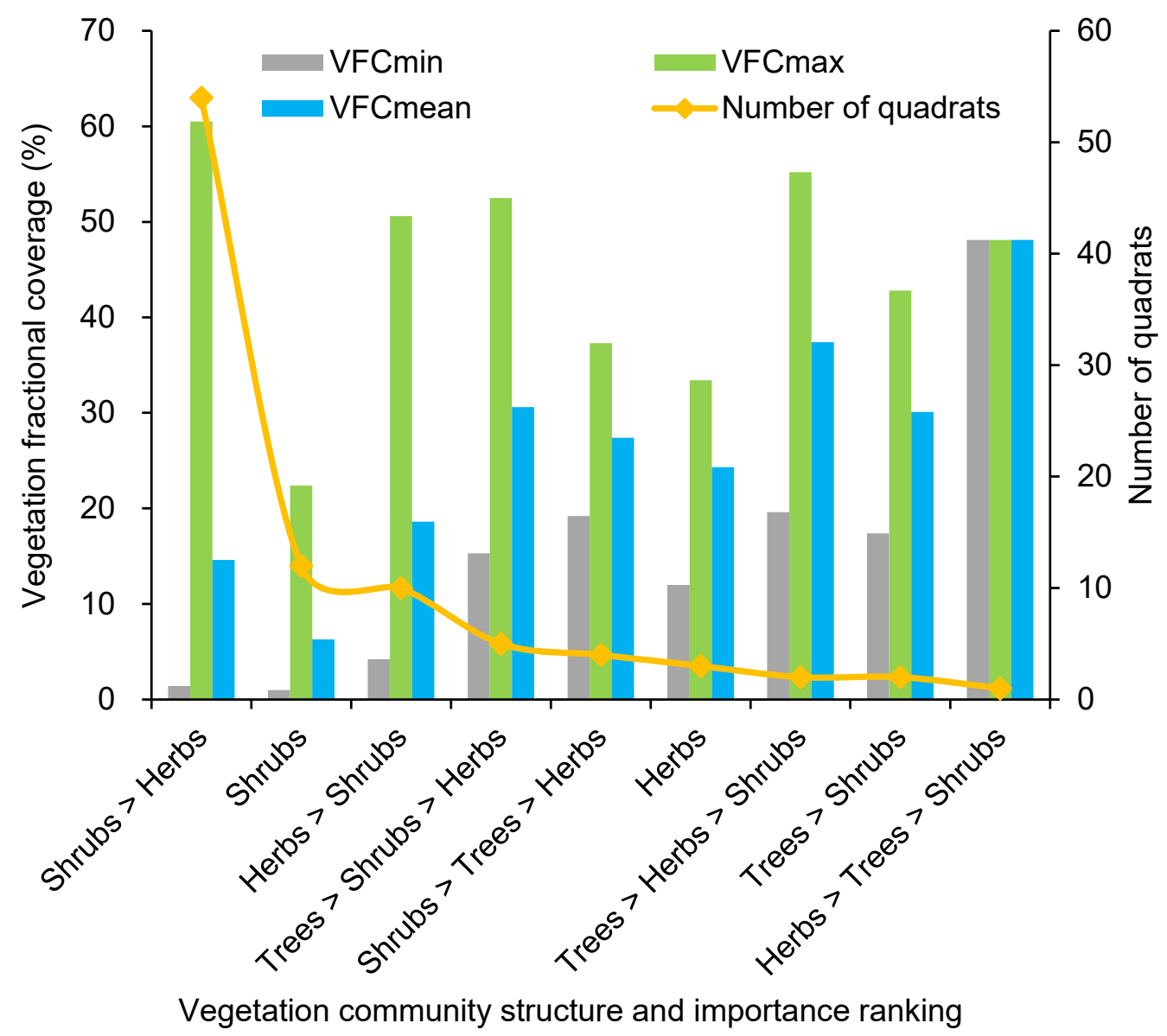

Figure 5. Statistics of vegetation community structure types and vegetation fractional coverage.

\section{Discussion}

\subsection{Ecological Relationship among Groundwater, Soil and Vegetation}

Figure 6 shows that the quadrats with higher vegetation fractional coverage were mainly concentrated in areas with shallow groundwater depth $(<6 \mathrm{~m})$ and relatively low surface soil salinity $(<5 \mathrm{~g} / \mathrm{kg})$. These samples were distributed in $\mathrm{WW}$, whereas the coverage rates of other areas were around 10-20\%. When the GWD was more than $10 \mathrm{~m}$, the VFC was less than $10 \%$ and the surface was bare soil, reflecting the poor overall ecological conditions of shallow-buried areas in the Shiyang River Basin. 


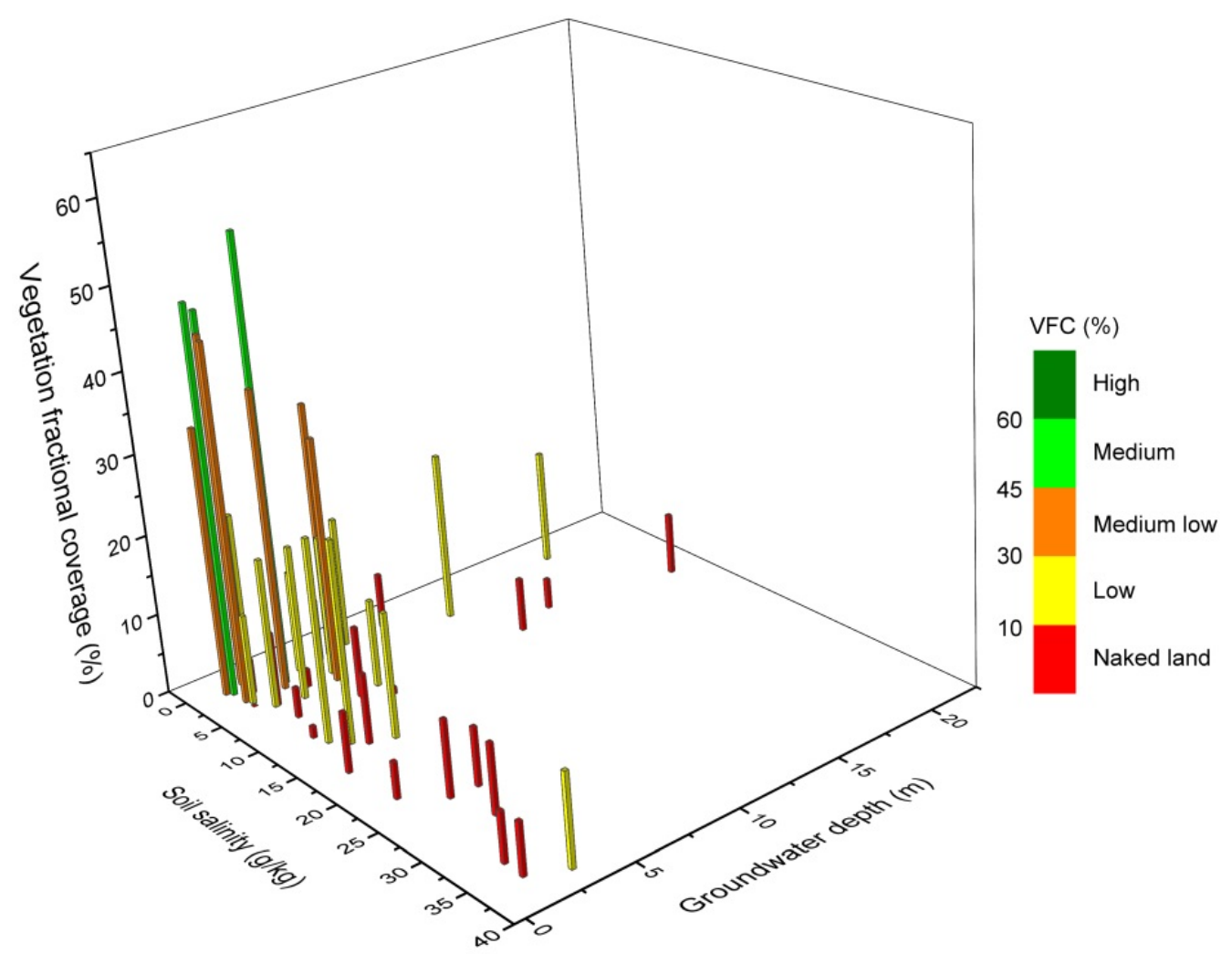

Figure 6. The vegetation fractional coverage (VFC) with different soil salinity and groundwater depth of the Shiyang River Basin.

The correlation analysis results of the water-soil-vegetation relationship showed that the VFC had the closest relationship with surface soil salinity, with a correlation coefficient between them of -0.43 , whereas the VFC correlation with GWD was only -0.21 . The relationship between GWD and vegetation growth was less obvious, meaning that the GWD does not significantly affect the VFC. Higher soil salinity may limit the types of vegetation and vegetation growth, resulting in a lower GWD that cannot produce high VFC.

To better understand the ecological effect of GWD and confirm the weak relationship between GWD depth and VFC, we analyzed the changes of GWD and vegetation conditions in a long time series. Figure 7 presents the change trend of groundwater from the 1980s to 2017. The GWDs of MQEE, NH, MQEW, WW, and MQW have trended upward. After 2012, the GWDs of the NH, MQEE, and MQW monitoring wells decreased and the water levels increased. After 2010, the GWD of the QTH area slowly decreased due to the implementation of ecological water transfer measures. As a wetland, the surface water area of QTH has also expanded $[19,24,45]$. The vegetation data in the same period show that, with the increase in GWD, the vegetation coverage conditions did not decrease significantly in the NH, WW, MQEW, and MQEE areas (Figure 8a,b,e,f). From the 1980s to 1996 and then from 2000 to 2017, the vegetation NDVI did not decrease significantly, but there were fluctuations. The average value of NDVI in MQW changed from 0.22 in 1980 to 0.15 in 1996, and subsequently remained stable at around 0.15 (Figure 8d). The NDVI of vegetation in QTH fluctuated around 0.13 from 1980 to 2010, and increased steadily after 2010 (corresponding to the decrease in GWD) (Figure 8c). 


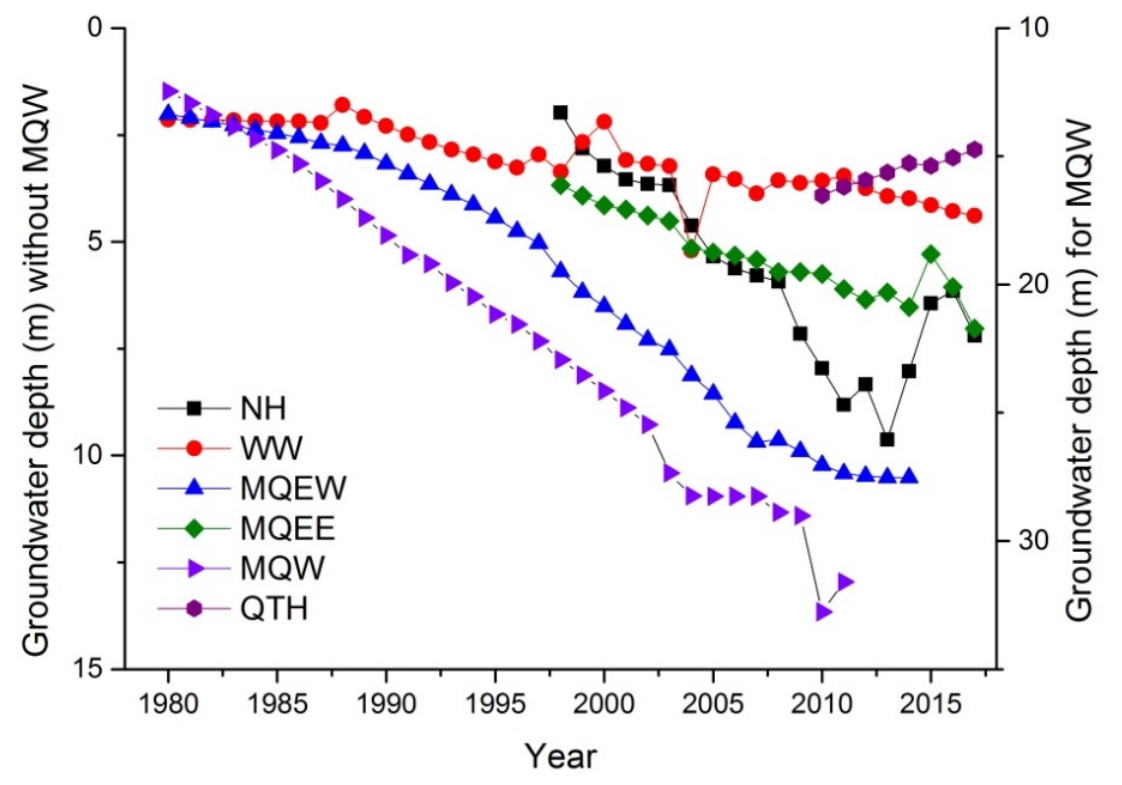

Figure 7. Variation of groundwater depth from 1980 to 2016.

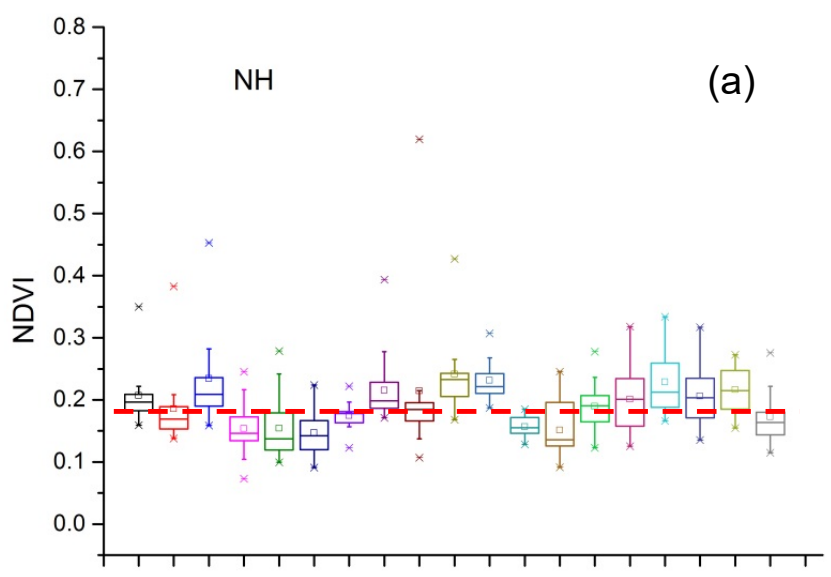

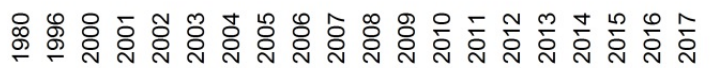
Year

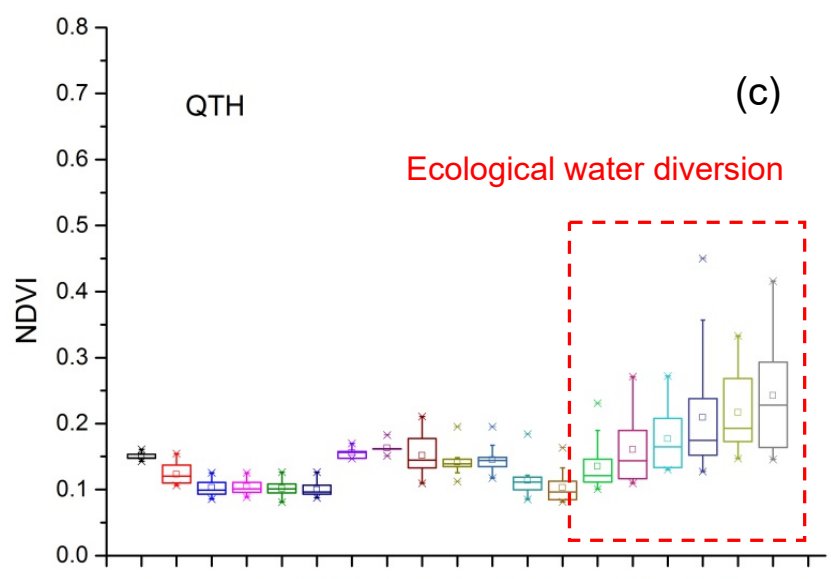

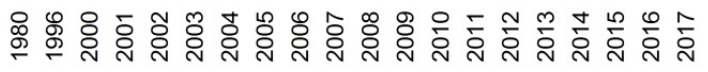

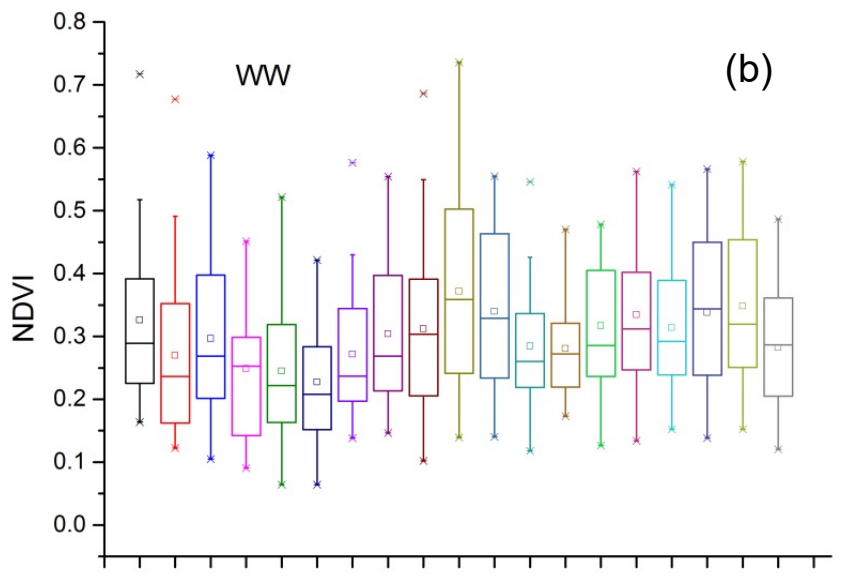

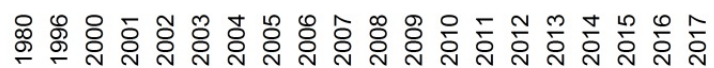

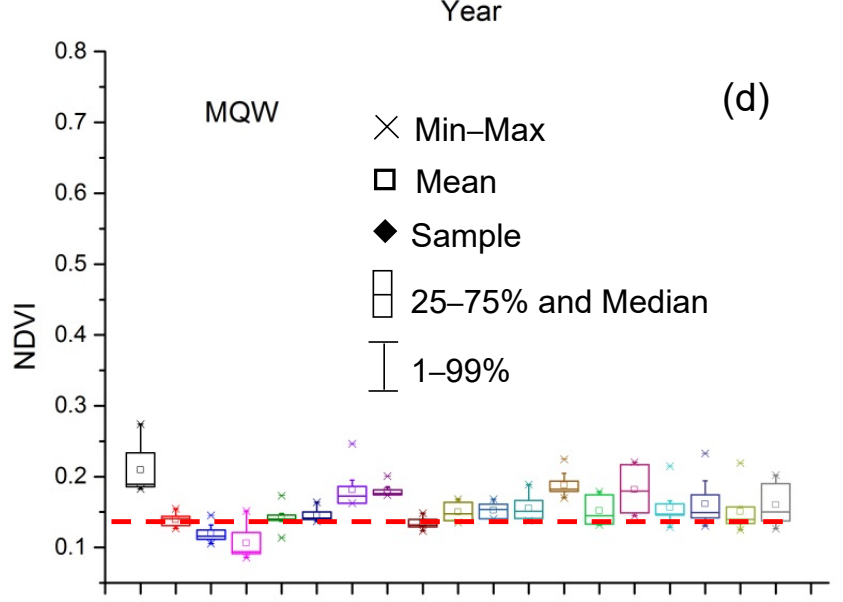

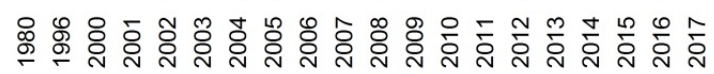
Year

Figure 8. Cont. 


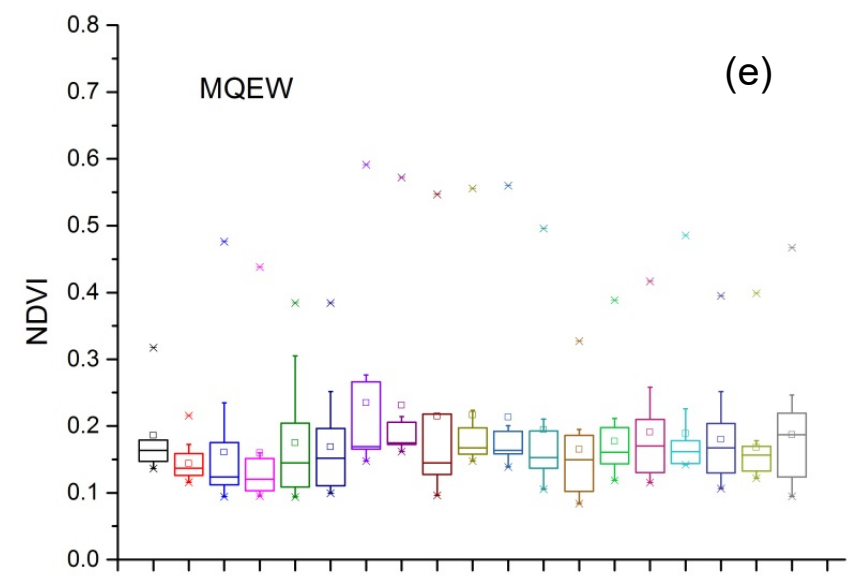

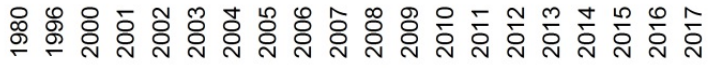
Year

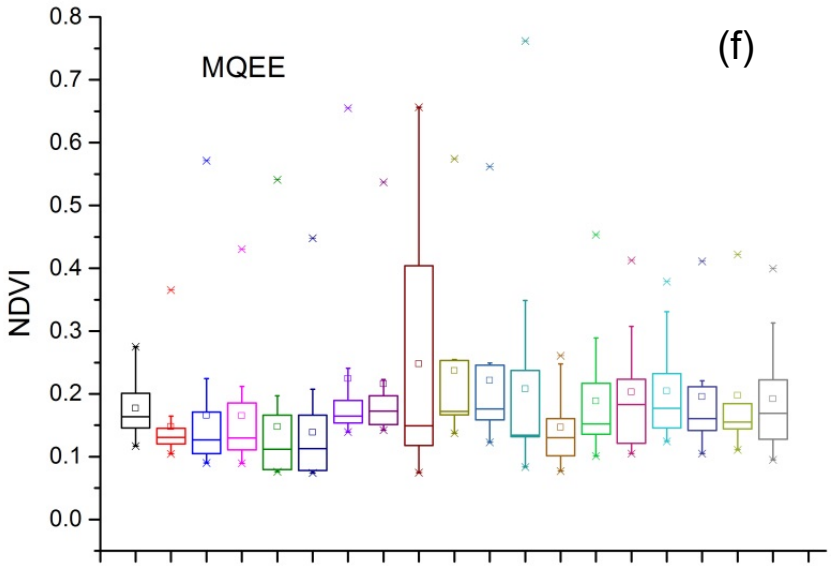

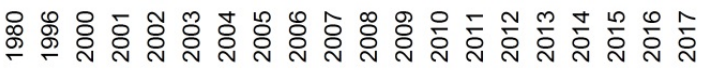
Year

Figure 8. Normalized difference vegetation index (NDVI) changes in different zones from 1980 to 2016. (a) NH; (b) WW; (c) QTH; (d) MQW; (e) MQEW; (f) MQEE.

In QTH, the buried depth was usually less than $3 \mathrm{~m}$, and the surface vegetation was consistent with the downward trend of ecological water transfer and buried depth, reflecting the ecological contribution of groundwater to the vegetation in the area. In other areas, the vegetation changes and buried depths were inconsistent with the evolution of GWD, indicating the weak influence of GWD and the close correlation between vegetation and surface soil. For areas with deeper GWD $(>10 \mathrm{~m})$, the soil moisture content is mainly affected by meteorological factors, such as precipitation, temperature, and relative humidity [34], especially summer precipitation. The meteorological data of the Minqin area from 2004 to 2017 (Figure 9) showed certain fluctuations in annual precipitation during this period. There were very high precipitation values in 2007, 2011, and 2014 and the fluctuations in annual precipitation and annual relative humidity were consistent with the change of vegetation NDVI in WW, NH, MQEW, and MQEE (Figure 10). This indicates that the growth of vegetation in these areas mainly depends on precipitation and soil water [21,46], and is not closely related to groundwater.

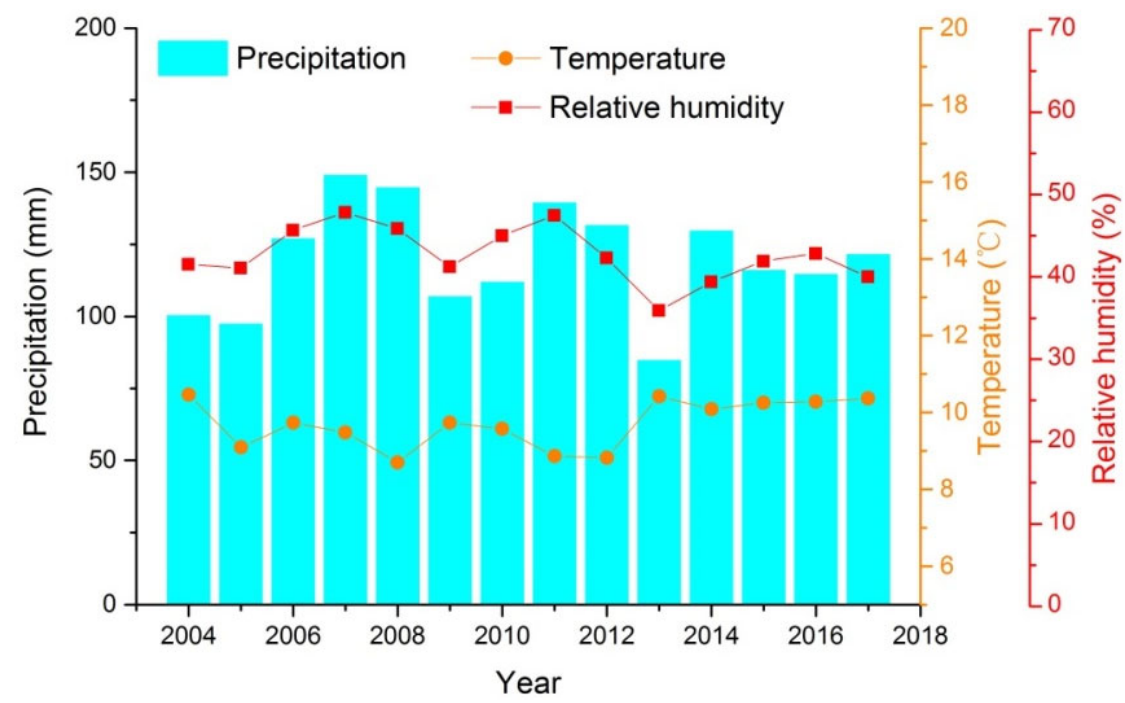

Figure 9. Meteorological changes in Minqin from 2004 to 2016. 


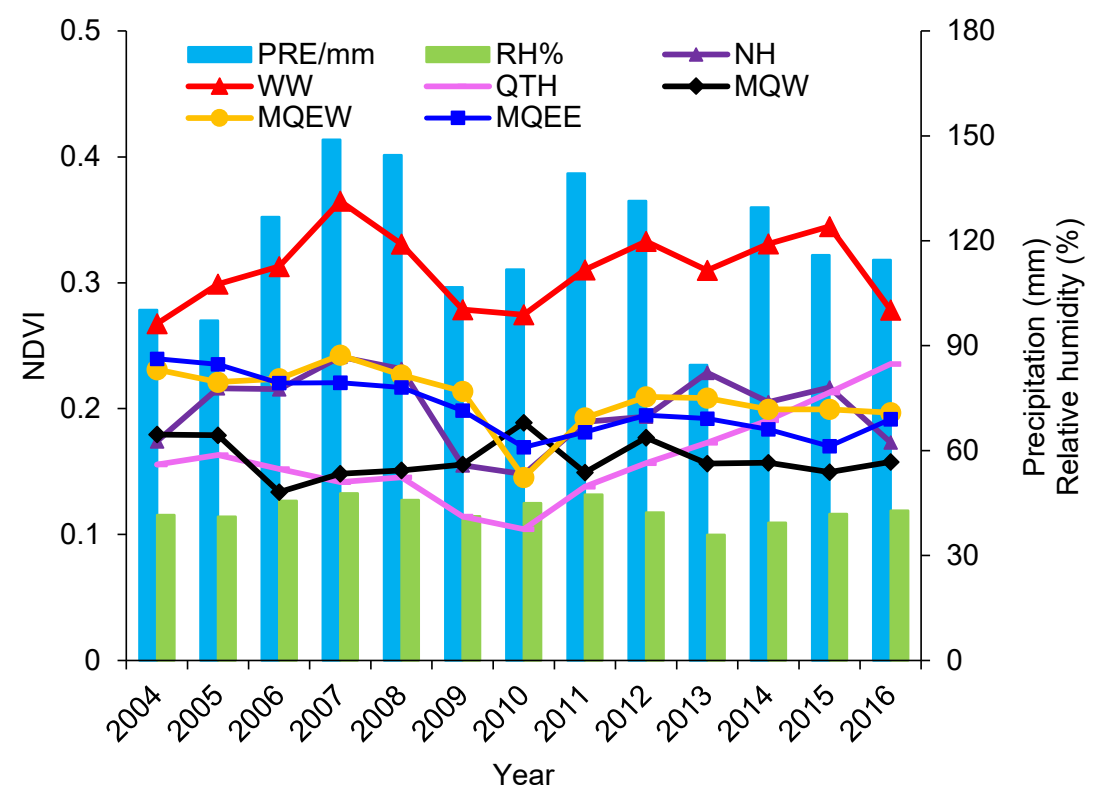

Figure 10. NDVI and meteorological factors changes in different zones from 2004 to 2016.

Among these areas, the VFC in the WW area had the closest relationship with precipitation with a correlation coefficient R of 0.63 (Table 2). This means that WW has a close relationship with the surface soil moisture content. Figure 11a shows all the quadrats and soil survey points in the WW area. According to the differences in GWD, these survey points were divided into three groups. When the local GWD was less than $2 \mathrm{~m}$ (Group 1), the soil moisture content and VFC were higher, and VFC reached 40-50\%. When GWD was about 2-4 m (Group 2), the relationship between VFC and soil moisture content was not significant and VFC ranged from $20-50 \%$. When the GWD was above $4 \mathrm{~m}$ (Group 3), VFC was less than $35 \%$ and there was a significant linear relationship between soil moisture content and VFC $(R=0.99)$. The higher the soil moisture content, the higher the VFC. From the perspective of community structure, Group 1 was composed of trees/shrubs and herbs, where shrubs were the dominant community, and marsh meadows were more developed [35]. Group 2 was dominated by a combination of trees, shrubs, and herbs, where trees were usually the dominant species. Group 3 included shrubs and herbs, where herbs were the dominant species in some of the quadrats. Desert vegetation communities in the Shiyang River Basin are usually composed of shrubs and herbs (Figure 5). The roots of shrubs and herbs in arid areas are mainly distributed at a depth of $1.2 \mathrm{~m}$ below the soil surface (Figure 12a) [47-50]. The water in this layer is the main water source that supports the growth of vegetation, which indicates the ecological significance of soil moisture in the surface unsaturated zone. For example, the root system of Haloxylon ammodendron is generally within $1 \mathrm{~m}$ of the surface, and the horizontal root system is concentrated $50-100 \mathrm{~cm}$ below the soil surface $[47,48,50]$. The root system of Tamarix spp. is distributed $40 \mathrm{~cm}$ below the soil surface. The roots of Nitraria spp. are distributed approximately $120 \mathrm{~cm}$ below the soil surface [47]. The main roots of the thin-branched Kalidium foliatum penetrate to $80-145 \mathrm{~cm}$ below the soil surface, where the main root system is distributed in the $10-30 \mathrm{~cm}$ soil layer, and the root width ranges from 100-115 cm [51]. For vegetation in the WW area, $4 \mathrm{~m}$ is an ecological water level boundary for the structure of the vegetation community (Figure 12a). When the GWD is greater than $4 \mathrm{~m}$, the vegetation of the community dominated by small shrubs and herbs mainly depends on summer precipitation and surface soil moisture for growth. The vegetation roots extend laterally to access water, especially in annual plants (Figure 12b). The degree of lushness is greatly affected by the total amount of precipitation and its annual and seasonal distribution. When the precipitation is appropriate, it can form Nitraria spp. + Calligonum shrubs and "Halogeton arachnoideus + Reaumuria soonorica shrubs with a coverage of more than $40 \%$. This type of vegetation has become an important 
part of the vegetation in this area [46,52]. The trees and some shrubs with a root depth of $4-10 \mathrm{~m}$ mainly rely on deep groundwater to survive $[49,53]$. When the GWD is less than $4 \mathrm{~m}$, the roots of the vegetation can grow vertically and penetrate the groundwater surface or reach the groundwater capillary water uplift zone (Figure 12c). Hence, the vegetation no longer completely depends on the surface soil moisture to survive. When the GWD is further reduced to $2 \mathrm{~m}$, vegetation growth can fully access soil moisture and groundwater to survive [54] (e.g., some species of Tamarix $[49,55]$ ), and thus VFC can reach a higher value [56]. Figure 11b displays the relationship between GWD and VFC when GWD $<4 \mathrm{~m}$. These two were highly negatively correlated $(R=-0.78)$. The smaller the buried depth, the higher the VFC. This was consistent with an analysis of the NDVI-GWD relationship in the Minqin Oasis conducted by Cao [25].

Table 2. Correlation analysis between NDVI and meteorological factors in different zones.

\begin{tabular}{ccccccc}
\hline $\mathbf{R}$ & WW & NH & MQW & MQEW & MQEE & QTH \\
\hline $\mathrm{n}$ & 12 & 12 & 3 & 11 & 5 & 4 \\
$\mathrm{PRE} / \mathrm{mm}$ & 0.63 & 0.30 & -0.43 & 0.17 & -0.05 & -0.13 \\
$\mathrm{TEM} /{ }^{\circ} \mathrm{C}$ & -0.29 & -0.15 & -0.05 & -0.06 & -0.12 & 0.49 \\
$\mathrm{RH} / \%$ & 0.23 & 0.03 & -0.25 & 0.04 & 0.09 & -0.37 \\
& $\mathrm{R}: 0$ & & & & & \\
\hline
\end{tabular}
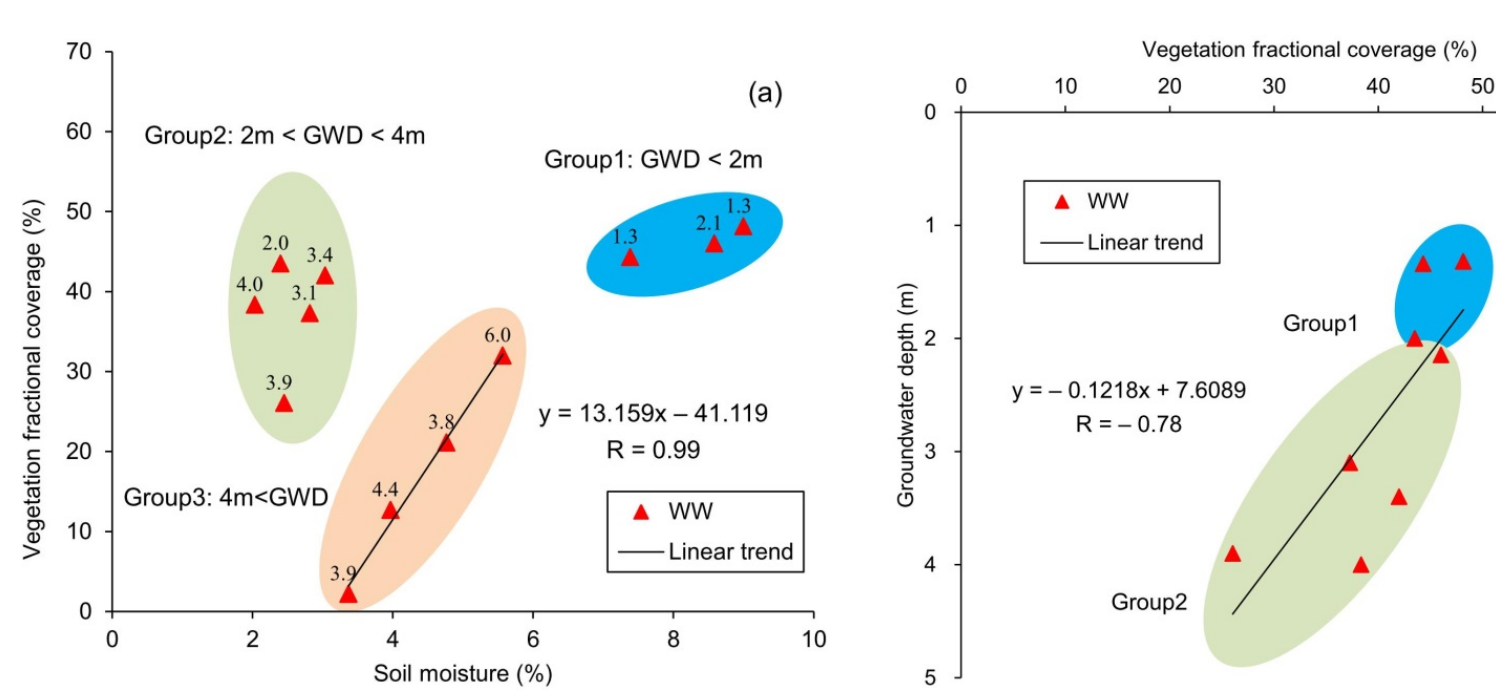

Figure 11. Relationship between vegetation fractional coverage (VFC) and soil moisture and groundwater depth (GWD): (a) VFC-soil moisture; (b) VFC-GWD.
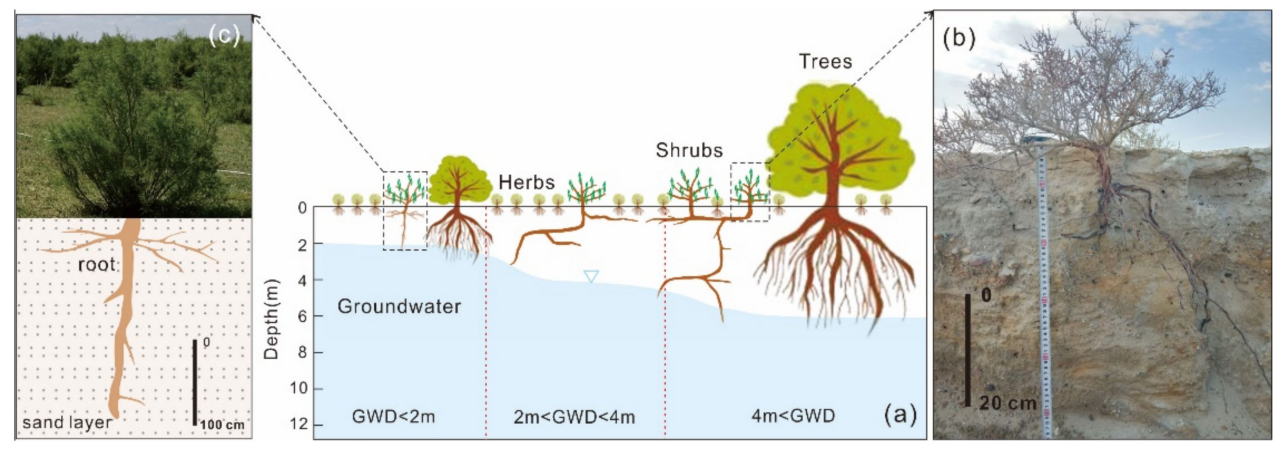

Figure 12. (a) Sketch of root distribution in the profiles of different groundwater depth in Shiyang River Basin; (b) Reaumuria soongorica; (c) Tamarix. 


\subsection{Ecological Degradation of Transition Zone Dominated by Groundwater}

Changes in the GWD can cause salinization and desertification [13]. A large GWD can result in reduced surface vegetation (as in MQW), which can in turn cause desertification (Figure 13), whereas a small GWD affected by surface evaporation can result in soil salinization. The growth of a small amount of salt-tolerant vegetation can limit the VFC [31], whereas lower vegetation cover can increase the risk of desertification. This process can make soil salinization a major environmental problem leading to land desertification $[57,58]$.

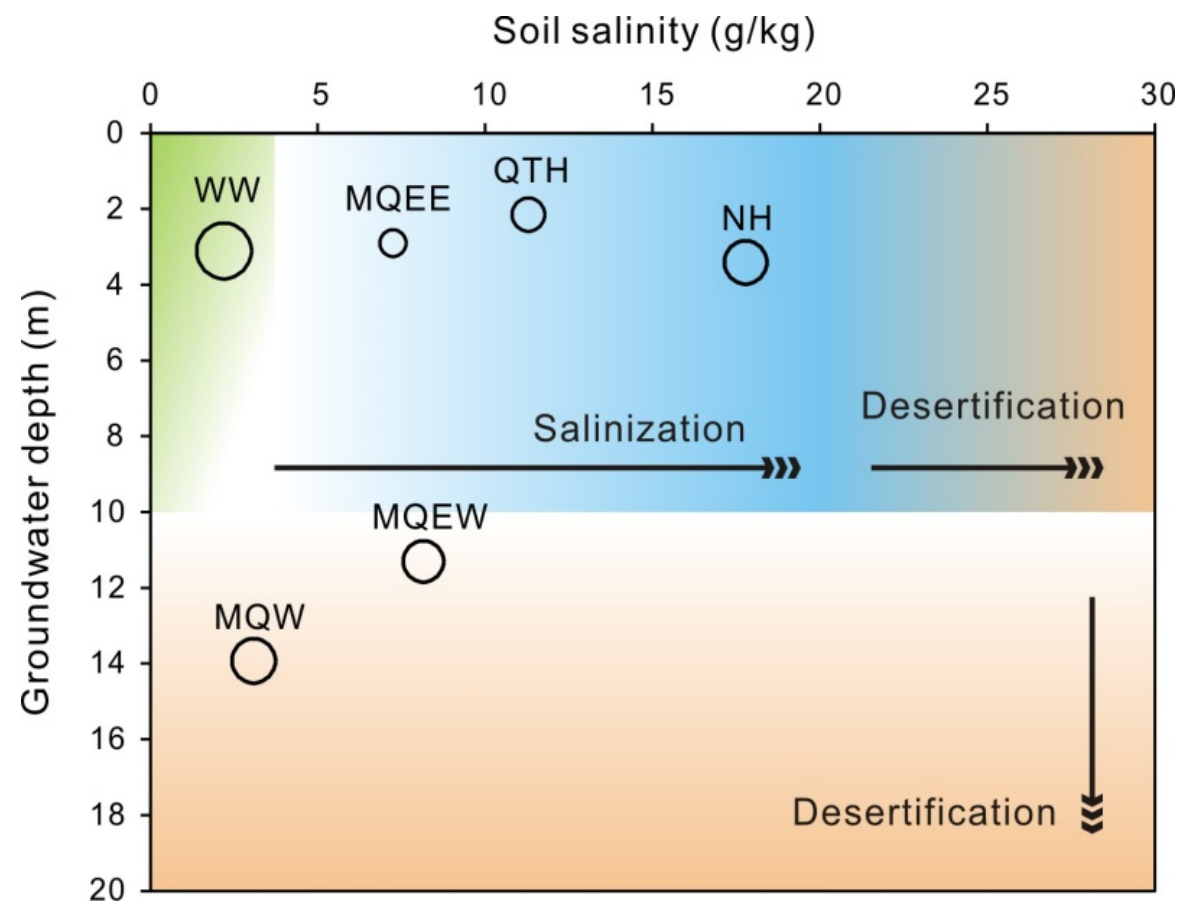

Figure 13. Ecological evolution process of desertification and salinization in shallow groundwater area of Shiyang River Basin. The circle size of each area represents the mean value of the number of vegetation species in the area, with the minimum of 2.6 and the maximum of 5.2; green represents the level of VFC, blue represents the level of salinization, and orange represents the level of desertification.

In addition to the WW area, the VFCs of other areas were not high, but their soil salinity values were above $3 \mathrm{~g} / \mathrm{kg}$ (Figure $2 \mathrm{~b}$ ). This suggested that the soil salinity may have constrained the VFC. For the NH area, with the highest salinity, the VFC was not high with scattered distribution of Kalidium foliatum and Sophora alopecuroides L. In the NH area, the correlation between $\mathrm{NH}$ and precipitation $(\mathrm{R}=0.3)$ was also smaller than that of WW $(\mathrm{R}=0.63)$, reflecting the obvious limitation of soil salinity on VFC. The expansion of the saline area in the Minqin Oasis and parts of the Qingtu Lake and the increase in salinity were mainly driven by ecological water transfer $[14,46]$. Figure 13 shows the relationship between desertification and salinization in the shallow buried area of the Shiyang River. When GWD was $<4 \mathrm{~m}$ and soil salinity was $<3 \mathrm{~g} / \mathrm{kg}$, the VFC was the highest and the number of species was the largest. There were 8-9 species of plants in the community of trees near the river bank (Figure 14). When the soil salinity was greater than $5 \mathrm{~g} / \mathrm{kg}, \mathrm{VFC}$ began to decrease. When the soil salinization reached $20 \mathrm{~g} / \mathrm{kg}$, it began to transform into bare land (Figure 6) and desertification occurred. When GWD was $>6 \mathrm{~m}$, the vegetation VFC began to drop. When GWD was $>10 \mathrm{~m}, \mathrm{VFC}$ was less than $10 \%$ and began to transform into bare land (Figure 6). 


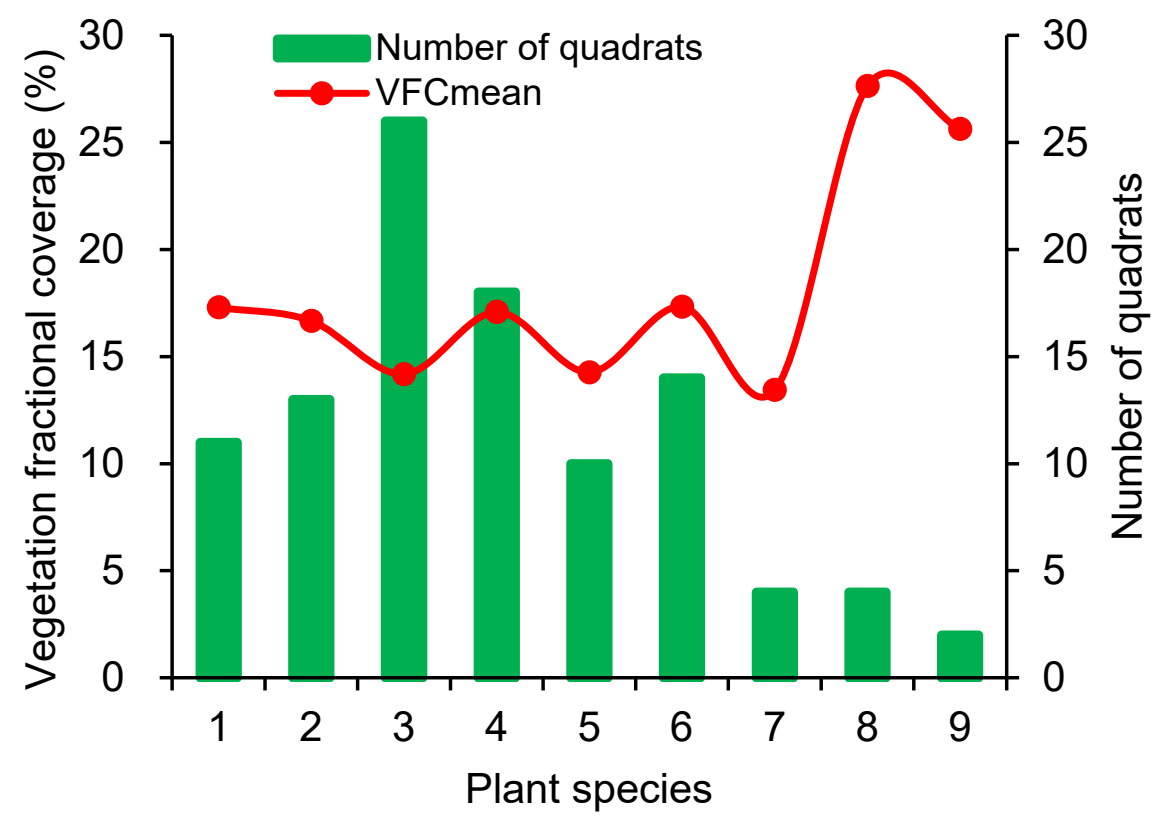

Figure 14. Statistics of species number, VFC and number of quadrats.

\subsection{Suggestions and Measures for Ecological Protection in Different Levels and Districts}

Over-exploitation of groundwater in the Shiyang River Basin has been detrimental. Since the 1960s, the groundwater level has declined significantly [25,38,59], and the ecological environment has deteriorated considerably. Since the implementation of ecological protection measures (such as ecological water transfer and a limitation on groundwater extraction), the initial achievements of ecological restoration in some areas have appeared $[25,37]$. The shallow groundwater area $(<10 \mathrm{~m})$ in the basin is the key area for protection and the easiest area for governance. Therefore, due to differences in GWD, soil quality, and salinity, it is necessary to implement targeted ecological protection measures at different levels. For the existing shallow groundwater areas, the WW area has a small GWD and low soil salinity. Its vegetation should be mainly protected by forest farms and grasslands. Groundwater exploitation in the riparian zone should be restricted. At the same time, attention should be paid to the salinization of areas with a GWD of less than $2 \mathrm{~m}$. The current ecological environment of QTH is significantly affected by ecological water transfer [24]. It is recommended to maintain the existing water transfer measures and gradually expand the impact on the ecological vegetation around the wetland. The soil salinity in the MQW and MQEW areas are not very high, and the main factor limiting VFC is a large GWD. By restricting groundwater exploitation in the irrigation area, planting and maintaining ecological forest construction, and expanding the ecological forests with small trees, we can expect ecological improvement, which may gradually serve as an effective barrier against the Badain Jaran Desert. The NH and MQEE areas had GWDs of less than $5 \mathrm{~m}$, but the high soil salinity limited the VFCs of these areas. Salinization control measures should be adopted in these areas.

\section{Conclusions}

In this work, the soil moisture, soil salinity, GWD, and VFC were integrated to study the ecological relationship of groundwater-soil-vegetation in Shiyang River Basin. The role of GWD and soil salinity in desertification and salinization were innovatively analyzed, and the key GWD and soil salinity standard for ecological vegetation maintenance and restoration were proposed. 
In the Shiyang River Basin, soil salinity is the factor most closely related to VFC and is inversely correlated with VFC $(R=-0.4)$. High salinity can significantly limit VFC. When soil salinity is greater than $3 \mathrm{~g} / \mathrm{kg}$, VFC is generally less than $20 \%$.

The surface vegetation community is dominated by shrubs and herbs. In the areas with soil salinity less than $3 \mathrm{~g} / \mathrm{kg}$, when GWD $>10 \mathrm{~m}$, the vegetation fractional coverage is usually less than $15 \%$. For areas with GWD $<10 \mathrm{~m}$, when GWD $>4 \mathrm{~m}$, VFC and soil moisture content are positively correlated $(R=0.99)$, or significantly affected by annual rainfall, and vegetation growth mainly depends on surface soil moisture. When GWD $<4 \mathrm{~m}$, VFC and GWD are negatively correlated $(\mathrm{R}=-0.78)$, and vegetation growth mostly relies on groundwater and soil moisture.

The water-soil-ecological conditions of the shallow-buried areas of the Shiyang River Basin have obvious differences, and ecological management measures should be formulated in specific areas.

Further work is required to better understand the water use strategies of typical vegetation under different GWD and salinization levels. In addition, it is beneficial to ecological protection to study the causes of soil salinity difference in the transition area.

Author Contributions: Conceptualization, L.C. and Z.N.; methodology, L.C. and M.L.; formal analysis, L.C.; investigation, L.C., M.L., L.W., J.W. and Q.W.; data curation, M.L., J.W. and Q.W.; writing—original draft preparation, L.C.; writing—review and editing, L.C. and J.W.; supervision, Z.N.; funding acquisition, Z.N. and M.L. All authors have read and agreed to the published version of the manuscript.

Funding: This research was funded by the National Key R\&D Program of China, grant number 2017YFC0406103; by the National Natural Science Foundation of China, grant nos. 41807214 and 41902262; by the China Geological Survey Project, grant number DD20190349.

Institutional Review Board Statement: Not applicable.

Informed Consent Statement: Not applicable.

Data Availability Statement: The data presented in this study are available on request from the corresponding author.

Acknowledgments: We thank Huixiong Lu and his team for their acquisition and collation of remote sensing data. Great thanks to the editors and anonymous reviewers for providing valuable comments that significantly improved this paper.

Conflicts of Interest: The authors declare no conflict of interest.

\section{References}

1. Odorico, P.D.; Bhattachan, A.; Davis, K.F; Ravi, S.; Runyan, C.W. Global desertification: Drivers and feedbacks. Adv. Water Resour. 2013, 51, 326-344. [CrossRef]

2. Yang, X.; Zhang, K.; Jia, B.; Ci, L. Desertification assessment in China: An overview. J. Arid Environ. 2005, 63, 517-531. [CrossRef]

3. Miyazono, S.; Patiño, R.; Taylor, C.M. Desertification, salinization, and biotic homogenization in a dryland river ecosystem. Sci. Total Environ. 2015, 511, 444-453. [CrossRef] [PubMed]

4. Zhang, Z.; Huisingh, D. Combating desertification in China: Monitoring, control, management and revegetation. J. Clean. Prod. 2018, 182, 765-775. [CrossRef]

5. Tao, W. Aeolian desertification and its control in Northern China. Int. Soil Water Conserv. Res. 2014, 2, 34-41. [CrossRef]

6. $\mathrm{Xu}, \mathrm{H} . ; \mathrm{Ye}, \mathrm{M}$.; $\mathrm{Li}, \mathrm{J}$. Changes in groundwater levels and the response of natural vegetation to transfer of water to the lower reaches of the Tarim River. J. Environ. Sci. 2007, 19, 1199-1207. [CrossRef]

7. Zhao, M.; Wang, W.; Wang, Z.; Chen, L.; Ma, Z.; Wang, Q. Water use of Salix in the variably unsaturated zone of a semiarid desert region based on in-situ observation. J. Hydrol. 2020, 591, 125579. [CrossRef]

8. Bhanja, S.N.; Malakar, P.; Mukherjee, A.; Rodell, M.; Mitra, P.; Sarkar, S. Using Satellite-Based Vegetation Cover as Indicator of Groundwater Storage in Natural Vegetation Areas. Geophys. Res. Lett. 2019, 46, 8082-8092. [CrossRef]

9. Jin, X.; Wan, L.; Zhang, Y.; Xue, Z.; Yin, Y. A Study of the Relationship between Vegetation Growth and Groundwater in the Yinchuan Plain. Earth Sci. Front. 2007, 14, 197-203. [CrossRef]

10. You, X.; Liu, J. Describing the spatial-temporal dynamics of groundwater-dependent vegetation (GDV): A theoretical methodology. Ecol. Model. 2018, 383, 127-137. [CrossRef] 
11. Zhang, H.; Wang, X.-S. The impact of groundwater depth on the spatial variance of vegetation index in the Ordos Plateau, China: A semivariogram analysis. J. Hydrol. 2020, 588, 125096. [CrossRef]

12. Johansen, O.M.; Andersen, D.K.; Ejrnæs, R.; Pedersen, M.L. Relations between vegetation and water level in groundwater dependent terrestrial ecosystems (GWDTEs). Limnologica 2018, 68, 130-141. [CrossRef]

13. Jin, X.; Hu, G.; Shi, X. Relationship between soil salinization and vegetation growing, groundwater depth in the Yinchuan Plain. Geoscince 2009, 23, 23-27.

14. Yang, J.; Zhao, J.; Zhu, G.; Wang, Y.; Ma, X.; Wang, J.; Guo, H.; Zhang, Y. Soil salinization in the oasis areas of downstream inland rivers-Case Study: Minqin oasis. Quat. Int. 2020, 537, 69-78. [CrossRef]

15. Sun, Q.; Zhang, P.; Sun, D.; Liu, A.; Dai, J. Desert vegetation-habitat complexes mapping using Gaofen-1 WFV (wide field of view) time series images in Minqin County, China. Int. J. Appl. Earth Obs. Geoinf. 2018, 73, 522-534. [CrossRef]

16. Ding, C.; Zhang, L.; Liao, M.; Feng, G.; Dong, J.; Ao, M.; Yu, Y. Quantifying the spatio-temporal patterns of dune migration near Minqin Oasis in northwestern China with time series of Landsat-8 and Sentinel-2 observations. Remote Sens. Environ. 2020, 236, 111498. [CrossRef]

17. Ren, X.; Yang, X.; Wang, Z.; Zhu, B.; Zhang, D.; Rioual, P. Geochemical evidence of the sources of aeolian sands and their transport pathways in the Minqin Oasis, northwestern China. Quat. Int. 2014, 334-335, 165-178. [CrossRef]

18. Dong, Z.; Man, D.; Luo, W.; Qian, G.; Wang, J.; Zhao, M.; Liu, S.; Zhu, G.; Zhu, S. Horizontal aeolian sediment flux in the Minqin area, a major source of Chinese dust storms. Geomorphology 2010, 116, 58-66. [CrossRef]

19. Feng, H.; Ochoa, C.G.; Xi, C.; Danrong, Z. Modeling oasis dynamics driven by ecological water diversion and implications for oasis restoration in arid endorheic basins. J. Hydrol. 2021, 593, 125774.

20. Wang, J.; Xie, Y.; Wang, X.; Dong, J.; Bie, Q. Detecting Patterns of Vegetation Gradual Changes (2001-2017) in Shiyang River Basin, Based on a Novel Framework. Remote Sens. 2019, 11, 2475. [CrossRef]

21. Li, L.; Wang, D.; Han, T. Spatial-temporal dynamics of vegetation coverage and responding to climate change in Shiyang River Basin during 2000-2015. J. Desert Res. 2018, 38. [CrossRef]

22. Huang, F.; Chunyu, X.; Zhang, D.; Chen, X.; Ochoa, C.G. A framework to assess the impact of ecological water conveyance on groundwater-dependent terrestrial ecosystems in arid inland river basins. Sci. Total Environ. 2020, 709, 136155. [CrossRef] [PubMed]

23. Huang, F.; Zhang, Y.; Zhang, D.; Chen, X. Environmental Groundwater Depth for Groundwater-Dependent Terrestrial Ecosystems in Arid/Semiarid Regions: A Review. Int. J. Environ. Res. Public Health 2019, 16, 763. [CrossRef] [PubMed]

24. Chunyu, X.; Huang, F.; Xia, Z.; Zhang, D.; Chen, X.; Xie, Y. Assessing the Ecological Effects of Water Transport to a Lake in Arid Regions: A Case Study of Qingtu Lake in Shiyang River Basin, Northwest China. Int. J. Environ. Res. Public Health 2019, 16, 145. [CrossRef]

25. Cao, L.; Nie, Z.; Liu, M.; Lu, H.; Wang, L. Changes in natural vegetation growth and groundwater depth and their relationship in the Minqin oasis in the Shiyang River Basin. Hydrogeol. Eng. Geol. 2020, 47, 25-33. [CrossRef]

26. Jin, X.; Wang, S.; Xia, W. Response of vegetation to variation in climate and groundwater in the Qaidam Basin. Hydrogeol. Eng. Geol. 2016, 43, 31-36. [CrossRef]

27. Jin, X. Quantitative relationship between the desert vegetation and groundwater depth in Ejina Oasis, the Heihe River Basin. Earth Sci. Front. 2010, 17, 181-186.

28. Dang, X.; Lu, N.; Gu, X.; Jin, X. Groundwater threshold of ecological vegetation in Qaidam Basin. Hydrogeol. Eng. Geol. 2019, 46, 1-8. [CrossRef]

29. Wang, J.; Zhang, G.; Cui, H.; Wang, Q.; Dong, H.; Hao, J. System index attribute and application of groundwater function zoning in northwest inland area of China. Shuili Xuebao 2020, 51, 796-804.

30. Wang, J.; Zhang, G.; Yan, M.; Tian, Y.; Wang, Q. Index weight analysis of groundwater function evaluation and zoning system in arid areas. Trans. Chin. Soc. Agric. Eng. 2020, 36, 133-143. [CrossRef]

31. Liu, F.; Chen, P.; Yu, H.; Ma, J. Spatial distribution characteristics of soil water and salt under different land use types in Minqin Oasis. Arid Land Geogr. 2020, 43, 406-414. [CrossRef]

32. Ma, Z.; Kang, S.; Zhang, L.; Tong, L.; Su, X. Analysis of impacts of climate variability and human activity on streamflow for a river basin in arid region of northwest China. J. Hydrol. 2008, 352, 239-249. [CrossRef]

33. Wang, X.; Chen, X.; Ding, Q.; Zhao, X.; Wang, X.; Ma, Z.; Lian, J. Vegetation and soil environmental factor characteristics, and their relationship at different desertification stages: A case study in the Minqin desert-oasis ecotone. Acta Ecol. Sin. 2018, 38, 1569-1580.

34. Zhang, Y.; Chang, Z. Study on the dynamic vegetation degeneration in the Minqin Desert Area. Arid Zone Res. 2008, 25, 16-21. [CrossRef]

35. Liu, H.; Liu, S.; Li, Y.; Yang, Z.; Li, Y. Response of riparian vegetation to the change of groundwater level at middle and lower reaches of the Shiyang River. Arid Zone Res. 2012, 29, 335-341.

36. Kang, S.; Xiaoling, S.U.; Tong, L.; Shi, P.; Yang, X.; Abe, Y.; Taisheng, D.U.; Shen, Q.; Zhang, J. The impacts of human activities on the water-land environment of the Shiyang River basin, an arid region in northwest China. Hydrol. Sci. J. 2004, 49, 413-427. [CrossRef]

37. Hao, Y.; Xie, Y.; Ma, J.; Zhang, W. The critical role of local policy effects in arid watershed groundwater resources sustainability: A case study in the Minqin oasis, China. Sci. Total Environ. 2017, 601-602, 1084-1096. [CrossRef] [PubMed] 
38. Yue, S.; Kang, S.Z.; Li, F.S.; Lu, Z. Comparison of interpolation methods for depth to groundwater and its temporal and spatial variations in the Minqin oasis of northwest China. Environ. Model. Softw. 2009, 24, 1163-1170.

39. Zhao, P.; Xu, X.; Qu, J.; Zhang, J.; Ma, Q.; Zhang, H.; Xu, G.; Ma, J.; WU, Y. Relationships between artificial Haloxylon ammodendron communities and soil-water factors in Minqin oasis-desert ecotone. Acta Ecol. Sin. 2017, 37, 1496-1505. [CrossRef]

40. Bao, S. Soil Agro-Chemistrical Analysis; China Agriculture Press: Beijing, China, 2005.

41. Tian, F.; Zhang, Y.; Lu, S. Spatial-temporal dynamics of cropland ecosystem water-use efficiency and the responses to agricultural water management in the Shiyang River Basin, northwestern China. Agric. Water Manag. 2020, 237, 106176. [CrossRef]

42. Wei, W.; Xie, B.; Zhang, X.; Zhang, J. Spatial Heterogeneity of Soil Moisture and Vegetation Cover in Shiyang River Basin, Northwest China. Earth Environ. Sci. 2019, 237, 052003. [CrossRef]

43. Zhang, S.; Ye, Z.; Chen, Y.; Xu, Y. Vegetation responses to an ecological water conveyance project in the lower reaches of the Heihe River basin. Ecohydrology 2017, 10, e1866. [CrossRef]

44. Li, M.; Wu, B.; Yan, C.; Zhou, W. Estimation of vegetation fraction in the upper basin of Miyun Reservoir by remote sensing. Resour. Sci. 2004, 26, 153-159.

45. Zhang, Y.; Zhu, G.; Ma, H.; Yang, J.; Pan, H.; Guo, H.; Wan, Q.; Yong, L. Effects of Ecological Water Conveyance on the Hydrochemistry of a Terminal Lake in an Inland River: A Case Study of Qingtu Lake in the Shiyang River Basin. Water 2019, 11, 1673. [CrossRef]

46. Mo, K.; Chen, Q.; Chen, C.; Zhang, J.; Wang, L.; Bao, Z. Spatiotemporal variation of correlation between vegetation cover and precipitation in an arid mountain-oasis river basin in northwest China. J. Hydrol. 2019, 574, 138-147. [CrossRef]

47. Chai, C.; Xu, X.; Tang, W.; Wang, F.; Wang, L. Root system of the main sand fixing plants in desert zone of Shiyanghe River Basin. J. Northwest For. Univ. 2009, 24, 21-26.

48. Sheng, J.; Qiao, Y.; Liu, H.; Zhai, Z.; Guo, Y. A study on the root system of Haloxylon Aammodendron (C. A. Mey.) Bunge. Acta Agrestia Sin. 2004, 12, 91-94.

49. Dong, Z.; Li, S.; Zhao, Y.; Lei, J.; Li, C. Stable oxygen-hydrogen isotopes reveal water use strategies of Tamarix taklamakanensis in the Taklimakan Desert, China. J. Arid Land 2020, 12, 115-129. [CrossRef]

50. Kebin, $Z$. The growth of man-made forests of Haloxylon ammodendron and their soil water contents in the Minqin desert region, Gansu Province, China. J. Arid Environ. 1989, 17, 109-115. [CrossRef]

51. Editorial board of Flora of China. Flora of China; Science Press: Beijing, China, 1979; Volume 25, p. 18.

52. Liu, H.; Wang, J.; Chang, Z.; Ma, Q.; Yang, Z.; Zhan, K. Characteristics of desert flora and vegetation in lower reach of Shiyang River Basin. Chin. J. Ecol. 2006, 25, 113-118.

53. Ehleringer, J.R.; Phillips, S.L.; Schuster, W.S.F.; Sandquist, D.R. Differential utilization of summer rains by desert plants. Oecologia 1991, 88, 430-434. [CrossRef]

54. McLendon, T.; Hubbard, P.J.; Martin, D.W. Partitioning the use of precipitation- and groundwater-derived moisture by vegetation in an arid ecosystem in California. J. Arid Environ. 2008, 72, 986-1001. [CrossRef]

55. Horton, J.L.; Clark, J.L. Water table decline alters growth and survival of Salix gooddingii and Tamarix chinensis seedlings. For. Ecol. Manag. 2001, 140, 239-247. [CrossRef]

56. Fu, B.; Burgher, I. Riparian vegetation NDVI dynamics and its relationship with climate, surface water and groundwater. J. Arid Environ. 2015, 113, 59-68. [CrossRef]

57. Amezketa, E. An integrated methodology for assessing soil salinization, a pre-condition for land desertification. J. Arid Environ. 2006, 67, 594-606. [CrossRef]

58. Thomas, D.S.G.; Middleton, N.J. Salinization: New perspectives on a major desertification issue. J. Arid Environ. 1993, 24, 95-105. [CrossRef]

59. Yang, H.; Feng, Q.; Guo, X. Variation of groundwater depth and its influence factors in the Minqin Oasis in 1999-2013. J. Desert Res. 2017, 37, 562-570. [CrossRef] 